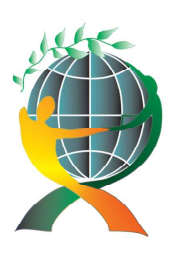

\author{
(online) $=$ ISSN $2285-3642$ \\ ISSN-L = $2285-3642$ \\ Journal of Economic Development, Environment and People \\ Volume 7, Issue 4, 2018
}

URL: http://jedep.spiruharet.ro

e-mail: office jedep@spiruharet.ro

\title{
Household budget: Impacts of incomes on consumption
}

\author{
Danilo Đikanović ${ }^{1}$, \\ ${ }^{1}$ University of Donja Gorica
}

\begin{abstract}
This research purpose is to explain the relation between several types of income and total personal consumption. Based on research method used, which is descriptive and regression analyses, the high influence of incomes on consumption is proven. Through various statistical results, it is shown in which extent the correlation is relevant and how it is concluded that the chosen variables are sufficient to explain the variation of the level of consumption through time. The main goal of this research is to discover what lies behind consumption and to understand the households as main consumption units on the market. Gained results are based on data analysis, in which the independent variables are "Income from pension insurance," "Income from property", "Income from small business" and "Wages and salaries," while the dependent variable is "Personal consumption". After testing all assumptions of linear regression and conducting the entire analysis, it is concluded that every independent variable is good in explaining the value of the dependent variable "Personal consumption". The statistical unit on which the analysis is based is a household, so statistics shown in this research are useful for understanding the essence of a budget in household economies.
\end{abstract}

Keywords: income, household, consumption, data analysis

JEL Codes: D12, D16

\section{Introduction}

What can a person spend? All consumptions are limited by incomes. Although, even if your incomes are on the level of zero, that does not mean that you will stop spending. Because it is related to future earnings such as dividends and profits, or future payments such as loans, people can find ways to continue their behavior on the market. Although, their behavior is quite susceptible to changes. Depending on their level of income and also, type of income, consumers behave differently. Taking into consideration that the market is unpredictable in a high level, companies and research institutes are investing time and money to create models or analysis, which can lower your risks of acting on the market. Why do they perform such activities? What is the purpose of research? Every research includes looking for clues, for answers, to create an image of the world. People and institutions have different motives, but their goals are often the same. The goal of every company is creating profit, although they can differ in their missions. New information, models, results of research are actually the instrument in making decisions. They help us to understand essentials of matters, so we can lower our risks and create a per say guideline in the business processes. 


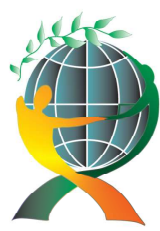

\author{
(online) $=$ ISSN $2285-3642$ \\ ISSN-L = 2285 - 3642 \\ Journal of Economic Development, Environment and People \\ Volume 7, Issue 1, 2018 \\ URL: $\underline{\text { http://jedep.spiruharet.ro }}$ \\ e-mail: office jedep@spiruharet.ro
}

Models are one way of simplifying the reality. Just as you know, your friend so well that you can predict how is he or she going to react in a certain situation or under certain conditions. In that way, marketing research can create a model to present the actions of consumers in a day life, as well as on the long terms. Our behavior can be affected by many factors, but we can use our logic and also scientific proofs to discover the core drivers of behaviors. This is a civilization based on money, where every aspect of our lives can be analyzed through science. In addition, what is the origin of science projects, in general? Companies and governments spend money to find new solutions to keep the economy going (or in the time of capitalism to keep the economy growing), when resources are becoming more scarce. They do it through investing in science projects, research projects. In this research, the aim is to get down to smaller subjects and track the behavior of units on micro level. Statistical units in this research will be households. It will show some causes of their behavior. Moreover, their behavior will be analyzed through money, more precisely, through their spending. This research will show spending to project trends and see how incomes affect economy on a micro level, how incomes affect personal consumptions. Although, expenses can still exist even the current level of income is zero. This research will be focused on incomes on a higher level.

The main idea of the relationship between income and expenditure is found in the consumption schedule or consumption outlooks in household economies. The assumption is that when disposable income rises, consumption increases. So if consumers have some extra money, they spend part of that income as well. There are some ways of measuring the increase of expenditures when income rises. That rate is called the marginal propensity to consume. For example, if someone has one income of $10.000 €$ per year, and spends $8.000 €$, the marginal propensity to consume is $8.000 / 10.000=0.8$. The remaining value is saved so the marginal propensity to save is 0.2 . In this research will be followed the logic that everything you have is everything you spend, having in mind that saving are a part of the expenditures. Nevertheless, people with lower incomes tend to have higher propensity to spend, if you look the savings and expenses as separated. This is important when the government creates variability of taxes and levels of welfare benefits. Taxes can affect many types of incomes, but in this research it will be used the one kind on which the effect is obvious. Thus is the level of profits made from business. A decrease in the marginal propensity to spend causes lower levels of consumption, for a given level of income.

To present possible view of these interactions, this marketing research will offer proofs through statistical analysis to show that the consumption is truly limited by incomes. Having in mind that there are many types of incomes and many ways to spend money, this research will be focused on several types of incomes and their effects on the total personal consumption. It can benefit not only the researchers, but also the investors, governments, companies, entrepreneurs and anyone who is studying the market as the reality in which we make decisions. Although this is only a simulation of a marketing research, there will be used real data from national statistic institute. 


\author{
(online) $=$ ISSN $2285-3642$ \\ ISSN-L = 2285-3642 \\ Journal of Economic Development, Environment and People \\ Volume 7, Issue 4, 2018 \\ URL: http://jedep.spiruharet.ro \\ e-mail: office jedep@spiruharet.ro
}

\title{
2. The context
}

\subsection{Research Objectives}

As every company has profit for its goal, every research estimates results in order to achieve its aspirations. Household budget provides much information, which can be used in different causes. Who can use them and why is important to have them will be discussed in this part of a research.

First, ministries and public administrations use statistical data gathered for the construction of household budget analysis. They use it in the purpose of economic and social policy planning. Then, the results of this research can be useful in gathering the data and their meaning about living conditions of private households. In this purposes, universities and research organizations use these data and results of analyses. As individuals, we can share the objectives of this research with private firms and consultants. Our common use of this research is directed towards analyses of consumption patterns of households in relation to the marketing of private consumer products. This information is often provided by mass media or through reports that show activities of national and international offices. Finally, the main objective is to use the research information in focusing on certain subjects such as the influence of the level of income on consumption patterns. More precisely, the goal is to measure the relation between several variables, the correlation between several types of incomes and total personal consumption.

This research share objectives with ones especially pointed out through the period when the conducting the household budget has began. Through decades, the prime objective of conducting the household budget research was to collect information on household consumption expenditures for use in updating the weights for the variety of incomes used in measuring the total personal consumption. The weight measures expenditures on specific incomes as a proportion of total expenditures. Through time, a number of uses and purposes have grown, so the surveys had to meet the requirement to give a new model, simplified picture of reality which represents living conditions of private households in certain areas and periods. In this research, the focus will be on a national level, based on units such as households in Montenegro. It will not focus on specific geographic areas, but will provide detailed descriptions of a private household's total consumption and expenditures, by household characteristics such as incomes.

To understand any topic, you will need to look underneath the surface. Therefore, in order to understand personal consumption and its objectives it is necessary to know why it has been chosen for the research. A large majority of economic output (nearly $70 \%$ ) is driven by personal consumption. It is the essence of economy on macro and micro level, as it is the main driver for this research. As an important economic indicator, personal consumption is, in every country, measured by gross domestic product. It is more likely to be recognized as a measure of national consumer spending. For example, it tells us how much residents of specific country spend on goods and services. Not only that, but it refers to incomes received by households in a country. 


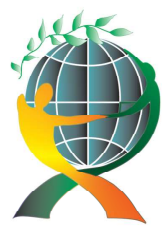

\author{
(online) $=$ ISSN $2285-3642$ \\ ISSN-L = $2285-3642$ \\ Journal of Economic Development, Environment and People \\ Volume 7, Issue 1, 2018 \\ URL: http://jedep.spiruharet.ro \\ e-mail: office jedep@spiruharet.ro
}

Some of the incomes, such as personal incomes include compensation from various sources. They include salaries and wages, and present the important source of income, which highly affects the personal consumption. That is why it has been chosen for this research and it will be proved by sophisticated economic analyses. The correlation between incomes and consumption is the core of this research, because personal income has a large effect on total consumption. Through the statistical analysis on which this marketing research is based, will be shown what the nature of this correlation is. Is it positive or negative? Will the rise of one-income increase the consumption in total? Or they act in a way that increase of an income decreases the consumption? Not only that, but it will show how strong is their correlation. The changes of variables through time can be anticipated, so this allows us to make assertions about how income and consumption trends are changing. For example, the National statistical office of Montenegro (MONSTAT) creates personal income statistics each month and they can be compared to numbers from the previous months. It can be used on the level of annual data also, but for this purpose it will be adequate to use quarterly data for several reasons. First, it is long enough to create an appropriate representation of changes through time. On the other hand, it is not too long period, which is good for this research, due to its nature and purpose. It is also appropriate regarding the limitations set through academic rules.

Personal consumption estimated through National statistical office includes in data the changes of costs, incomes etc. With these changes included in data we can analyze how changes in personal income truly affect spending. For example, if there is a significant increase of some type of income, households may have more money in cash, but they will probably spend more on goods and services from basic consumer's basket. That is why income is the main instrument used in this research: income is the money that you receive as an individual or organization, perhaps business, in exchange for providing a good or service. It is the universal good that allows us to buy all other goods; it enables us to consume something we cannot create on our own, or is inefficient to do it personally.

As earlier has been mentioned, one of the incomes, which is used in this research to measure the relation with the consumption, is income from wages and salaries. The most expenditure is based on daily consumptions and they are provided through income from wages and salaries earned from a job, for most of the people aged under 65 . In other words, their main source of income is exactly the job earnings. That is why it is included as an important indicator for evaluating trends of consumption.

For people aged above 65 in most of the countries their main source of income is from pension insurance. That is why it has been listed as the second variable important to understand the effects on personal consumption. As the economy moves up and down, analysts develop trends that help governments create their policies. Having in mind that the population is ageing, the big influence on political and economic trends has actions regarding part of the population that is retired. The reason is that they are (in European Union, also in Montenegro) the majority and can create the biggest influence through democratic system on the stability of economy on a macro level, and the most important fact, it 


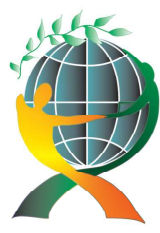

\author{
(online) $=$ ISSN $2285-3642$ \\ ISSN-L = $2285-3642$ \\ Journal of Economic Development, Environment and People \\ Volume 7, Issue 4, 2018 \\ URL: http://jedep.spiruharet.ro \\ e-mail: office jedep@spiruharet.ro
}

will reflect on the households and their possible levels of consumption. So changes in population, policies and pension system are interdependent and influence the personal consumption.

There are many more factors, but for the purpose of the research there will be used two more variables which create important impact regarding objectives of this study. Those are the incomes from property and income from small business. The reason why they have been chosen is the clear movement of their values on a quarterly and yearly level, so they represent a good base for estimating the correlation between variables. For example, level of incomes from property has been changed a lot during the last decade, due to economy crises that decreased the level of their value around the end of the first decade of 21st century. National statistical office shows that these incomes are likely to be spent on basic goods and services, which are parts of total personal consumption. The incomes from property are still not stabilized if we compare them to the previous conditions of "healthier" economic environment, but it had many changes during the second decade of this century. This created impact big enough to be recognized in statistical reports over the years.

Every economy is based on a big number of small and medium sized businesses. Their effect on the economy is often only measured on the national level, but their reasons for start ups were not for the purpose of public interests. As for individual needs, businesses are created to satisfy the needs of their creators. Again, we are asking ourselves what is beneath the surface. The value, which entrepreneurs create directly, affects their possible levels of personal consumptions. Thus, it is an important factor to realize while measuring the consumption on the individual level, as well as on the level of households. In this research it will be used the data of average household consumptions on quarterly level, as well as the data of average income from small and medium sized business.

\title{
2.2. Background information
}

In 2010, respectable economists Tullio Jappelli (Director of the Center for Studies in Economics and Finance) and Luigi Pistafferi (Professor at Stanford University) wrote a research based policy analysis on the subject "The consumption response to income changes". This research shows proofs from various sources and suggests if financial market arrangements and liquidity constraints are biding, changes in income make a significant effect on consumption.

Their work has one different approach than mine, in a way that they support the idea that tax changes have a considerable impact on expenditure. It is reasonable to assume that, if we know that taxes are reducing our profits, wages and salaries, and that taxes increases bills of electricity, real estates, water etc. Simply put, taxes are fixed costs for services that countries serve. Depending on the level of fixed costs, we will have more or less money to spend on other services offered by nongovernmental subjects. Those expenses are the personal consumption. This research will not be focused on the factors that impact the income, but will examine in which level income affects personal consumption. The similarity of the research 


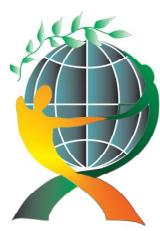

\author{
(online) $=$ ISSN $2285-3642$ \\ ISSN-L = $2285-3642$ \\ Journal of Economic Development, Environment and People \\ Volume 7, Issue 1, 2018 \\ URL: http://jedep.spiruharet.ro \\ e-mail: office jedep@spiruharet.ro
}

written by Jappelli and Pistafferi with this research are the economic conditions in which analysis are conducted. By economic conditions is meant on the period from 2008 until the year of 2015. This period is interesting because of the crises caused by shock on the financial market. It is clear that it had effects on income, especially on the incomes from property, business and wages. Thereafter the effect of income from pension came to place, due to changed governmental economic policies. That is why those incomes have been chosen for the research, because the economic period created fluctuations of incomes. Statistical analysis in the next chapters of this research will make that clear.

Last couple of years witnessed some level of economic recovery, so economists put focus again on the link between consumption and income. That is when Jappeli and Pistafferi started their research to measure past and after effects of different economic conditions. The connection between these two variables (income and consumption) is not new, but there is still a lack of precise answers on these questions: How does household consumption responds to changes in economic resources; how much the response depends on the level of changes? Those are the questions on which the research of mentioned, but the two authors did not offered answers; this research will quantify those effects.

Nevertheless, these two economists have examined household budget in a slightly different way. They have considered the effect of expected income on consumption. Most famous example of expected income is in the conditions of retirement. Their results were that expected income decreases consumption. There are psychological aspects of decision making which can be logical, for example, that younger people are more willing to take high risks and consume more because they have more time to recover from potential loses. This research will not go further to examine those effects, but will be based on concrete statistical facts and not on economic theories based on psychological effect, because they are more difficult to measure, due to unreliable data. Other outcomes of the past research on household budget, written by mentioned economists, are related to tax changes and what they depend on. Precise effects of tax changes depend on whether the policy is anticipated, whether taxes increase or decline, and are the change perceived as temporary or permanent.

Therefore, the differences in our approaches are in the idea that all changes of incomes are relative. They do depend on taxes, but it is not relevant for this research. On the other hand, tax changes are more permanent than temporary. They are applied in the system for at least months and can last for many years. So their research had challenge for empirical work at evaluating fiscal packages with the impacts of different tax policies which are implemented. To reflect their impact on the personal consumption, this research chose changes that are more dynamic.

In 2016, institution named "The PEW Charitable Trust" led a research and analysis on the subject "Household expenditures and income". As explained above, it is not new to analyze relation between these two economic indicators, but every research is different in the approach and its objectives. The PEW's research had a general focus on the household financial security. In that sense, it is common to pay 


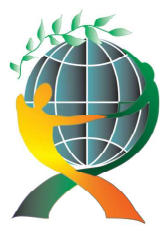

\author{
(online) $=$ ISSN $2285-3642$ \\ ISSN-L = 2285 - 3642 \\ Journal of Economic Development, Environment and People \\ Volume 7, Issue 4, 2018 \\ URL: http://jedep.spiruharet.ro \\ e-mail: office jedep@spiruharet.ro
}

attention to income, but their research also made effort to determine whether incomes are sufficient to cover expenses. Their methodology is based on the use of the Bureau of Labor Statistics' Consumer Expenditure Survey, in order to evaluate household consumption.

As in this research, they examined changes in consumption. Their research is based on a longer period, from 1996 to 2014. This research analyzes changes in the period from 2008 to 2015. But, this research uses quarterly data which gives more structural information. On the other hand, PEW's research details the differences in expenditures by every income separately, while this research creates an image of total personal consumption whose variability is analyzed through changes in every income. In other words, it examines the impact of all incomes on total personal consumption. Indirectly, through coefficients of correlations can be calculated the effect of every income on the consumption separately, but it won't be primal objective to this research. Other differences are obvious in the target population used for each research. The PEW's Charitable Trust institution focused on the working-age population, which includes survey respondents aged between 20 and 60 . They also divided the sample into thirds. This research is primarily based on a statistical analysis of secondary data provided by the National statistical office. It also does not divide the sample in parts. While PEW's research was limited on a working population, this research will overcome that limitation. It is based on analysis of households, which includes households whose members are sometimes retired. That is why this research uses income from pension insurance as a variable to evaluate effects of wider types of households on personal consumption.

Now, there are some similarities between these researches. They both show changes of income and consumption after the period of crisis, reflecting economic turnovers of the country. The PEW's research examined household spending to show impact on family financial security over time. Their key findings include that overall median household expenditures grew by about 25\% between 1996 and 2014. Results show that expenditures have returned to pre-crises levels, especially in the period of last three years. Assumption of this research is also that consumption has increased during the last years; in the next chapters of the research, through analysis, this will be explained and examined. It is logical that expenses have increased due to the economic recovering on a national and international level during the years, but this research will show what had the biggest influence on personal consumption. The PEW's research had another key finding, reflected in a result that although expenditures recovered from the downturn, income did not. It is very possible that incomes have not recovered from the period of crises, but only in some types of incomes!

Some markets, like real estate market in Montenegro, are still not on a high level of development, as they were around 12 years ago. However, this research will show that incomes show changes during the years or that they are stable enough to cover the expenses. In other words, as opponent to PEW's research it is based on assumption that incomes used in this research are big enough to cover the expenses. It is based on a methodology used by National statistical office in order to collect data, which are proven to cover at least minimal consumption, as a standard required by the European Union institutions and the 


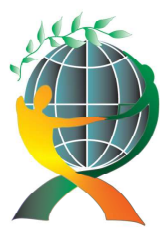

\author{
(online) $=$ ISSN $2285-3642$ \\ ISSN-L = $2285-3642$ \\ Journal of Economic Development, Environment and People \\ Volume 7, Issue 1, 2018 \\ URL: http://jedep.spiruharet.ro \\ e-mail: office jedep@spiruharet.ro
}

World Health Organization. So, this research is not focused on the idea that incomes are not enough to support household consumption, but it is focused on determining which factors or types of incomes influence the consumption and at what level. Finally, the PEW's research focused on financial independence of households. Therefore, they examined categories of consumption such as food, housing and other living expenses. This research is based on the total personal consumption showing changes through variations in incomes and not through structural changes of consumption.

\title{
2.3. Hypothesis
}

This research has its objectives based on giving answers to four questions. These questions are formed as hypothesis, which marketing research based on statistical analysis will test:

1. Ho: Wages and salaries affect the total personal consumption

H1: Wages and salaries do not affect the total personal consumption

2. Ho: Income from property affects the total personal consumption

$\mathrm{H} 1$ : Income from property does not affect the total personal consumption

3. Ho: Income from pension insurance affects the total personal consumption

$\mathrm{H} 1$ : Income from pension insurance does not affect the total personal consumption

4. Ho: Income from small business affects the total personal consumption

$\mathrm{H} 1$ : Income from small business does not affect the total personal consumption

Ho is the "null" hypothesis, which this research will try to prove. If the results are negative, for example in the first objective, it means that it is not correct that wages and salaries affect the total personal consumption. If this is the case, alternative hypothesis $\mathrm{H} 1$ is the statement following results will prove and that is the conclusion evaluated to be correct.

First it will be explained why these correlations have been assumed through observation method, based on logic, common sense and personal experience. Then the assumptions will be followed by statistical data through cross tabulations. Wages and salaries are the main financial resource for large majority of people. Around $5 \%$ of all people are considered as entrepreneurs. In other words, 5 of 100 people will be the ones who create companies and one part of rest of the people will work for them. Some people will work in private companies or the ones led by governments. But, in both cases their work as a price and they will gain wages and salaries. On the other hand, entrepreneurs will create profit. There is a difference in these two incomes and that is why the taxes are specially formed for wages and especially for profits. In addition, that is the reason why national statistical offices measure their values separately. Profits are usually much bigger than individual wage of a worker in the company that created the profit. So, they affect the economy more. However, if we combine all values of wages and salaries, they also make a significant impact on the economic system. Thus, it is not odd to hear that countries are based on small and medium sized enterprises. Because, everywhere around us we see markets, bars, shops, fashion houses, fast foods. We see products, services and somebody made them and put on the market for people to buy. For services, they provide they gain profits, wages and salaries. So consumption is possible because of the 


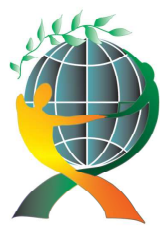

\author{
(online) $=$ ISSN $2285-3642$ \\ ISSN-L = $2285-3642$ \\ Journal of Economic Development, Environment and People \\ Volume 7, Issue 4, 2018 \\ URL: http://jedep.spiruharet.ro \\ e-mail: office jedep@spiruharet.ro
}

people and organizations who satisfy our needs in order to earn money. That is the core of the economy, so it clears why incomes from business, wages and salaries have been chosen to represent the background value of consumption.

Statistical units used for analysis in this research are households. That means that they have in average around three members. Two are usually the parents and other members are children. As the children grow up, parents earn money so they can have resources on which the consumption of the household is based. That money is mostly income like profit or salary. When years pass and children are mature citizens ready for the job market, parents are preparing for retirement. So, their income will change. At that time, they will receive money from pension insurance to cover their expenses. In the same time, their children made new, individual households whose main resources are wages and profits. But, there is another fact that should be considered. As many research institutions mention, the population of Europe is ageing. The average age in countries is getting higher and that is the case in Montenegro. According to the National statistical office of Montenegro, birth rate is decreasing. That partly proves the fact which politicians are aware of, that democratic process in this region is based on choices made by elders. Elders are the main market and there is a good probability that it is not much different on the economic markets. While parents and people in retirement create the money, products and services, it is obvious that children are only the consumers. As this is research that analyses the consumption through incomes which are created by more and more older population, it is clear that income from pension insurance can be a significant factor that affects the total personal consumption of households.

Apart of these three mentioned incomes, there are more ways to create resources necessary for covering the consumptions. Wages are often not enough to cover all of the expenses in the present time. On the other side, it is pointed out that only about $5 \%$ of population creates companies. So the question is: how else do people get the money? One answer is with the help of bank loans. Other way is through investments on the capital market. However, dividends are not often paid out and they assume some level of risk for the investors. On the other hand, bank loans also create costs. That money comes with the price and the interest is often not small, depending on the type of the loan and conditions of exchange. In Montenegro is not a rare way of earning money using the private property. Many people buy additional flat or land, so they can rent it or sell it. During the first several years of the new millennium, there were good opportunities in Montenegro to earn money through property. When the crises affected the economy, that market had big decreases of values and it became hard to use your property for financial purposes. But in recent years, especially in the year of 2015, many economists around the world noticed that the market is becoming dynamic again. Market in Montenegro also had some changes in the last decade, so using the income from property as a factor to explain variations in the level of consumption can be a useful tool. This is the reason that we can be surer of the correlation between variables and we can examine the effects due to the changes of one variable on the other one. 


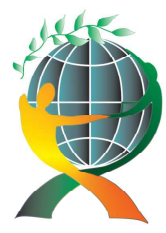

\author{
(online) $=$ ISSN $2285-3642$ \\ ISSN-L = $2285-3642$ \\ Journal of Economic Development, Environment and People \\ Volume 7, Issue 1, 2018
}

URL: http://jedep.spiruharet.ro

e-mail: office jedep@spiruharet.ro

Table no.1 General tendencies of variables through time

\begin{tabular}{|r|c|c|c|c|c|}
\hline \multicolumn{1}{|l|}{} & & & & & \\
Year & Income from property & Income from insurance & Wages and salaries & Income from small business & Consumption \\
\hline 2015 & Increase & Increase & Decrease & Increase & Decrease \\
2014 & Decrease & Increase & Decrease & Increase & Increase \\
2013 & Decrease & Increase & Increase & Decrease & Decrease \\
2012 & Decrease & Decrease & Increase & Increase & Increase \\
2011 & Increase & Increase & Decrease & Decrease & Decrease \\
2010 & Decrease & Increase & Decrease & Decrease & Decrease \\
2009 & Decrease & Decrease & Increase & Increase & Increase \\
2008 & - & - & - & - & - \\
\hline
\end{tabular}

This cross table shows the variations of the variables by generalizing their changes. The data used from the National statistical office bases are presented on monthly level and in the statistical analysis in this research they have been edited in quarterly data. However, for the purpose of creating trends this table shows changes in bigger periods. Annual results show that income from property had decreases from year to year, which proves the economic condition of properties during the years of crises. As the birth rate in Montenegro has negative trend, this table shows clear results of government policies based on the population which they have to take care of. Wages and salaries had increases and decreases, which can be useful for examination of those effects on the personal consumption. Because, if the variables are likely to be more constant values, it would be small possibility to explain the variations of the dependant variable, which in this case is consumption. Income from business also has many changes, but their impact is greater than it can be seen through cross tabulation. Profits had enormous increases and their correlation with the consumption will be clearer in the next part of this research, using regression and other advanced statistical analyses. Nevertheless, we can already see that almost every change in the income from small business follows the change in the personal consumption.

Table no. 2 Variables grouped according to general tendencies

\begin{tabular}{|c|c|c|c|c|c|c|c|}
\hline Number of variables & $\mathbf{2 0 1 5}$ & $\mathbf{2 0 1 4}$ & $\mathbf{2 0 1 3}$ & $\mathbf{2 0 1 2}$ & $\mathbf{2 0 1 1}$ & $\mathbf{2 0 1 0}$ & $\mathbf{2 0 0 9}$ \\
\hline Increased & 3 & 3 (C) & 2 & 3 C & 2 & 1 & 3 (C) \\
Decreased & 2 (C) & 2 & 3 (C) & 2 & 3 (C) & 4 (C) & 2 \\
\hline Total & 5 & 5 & 5 & 5 & 5 & 5 & 5 \\
\hline
\end{tabular}

This table shows the logical movements of the dependant variable. The letter " $\mathrm{C}$ " represents the personal consumption. As it can be seen, in most of the cases, dependant variable followed the variations of the independent variables. When there are more variables whose annual results are seen as increases, the consumption was among those variables. While when the most variables resulted in decreased values, the consumption was almost in every case among those variables. So it can be already assumed that 


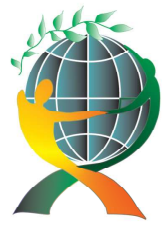

\author{
(online) $=$ ISSN $2285-3642$ \\ ISSN-L = $2285-3642$ \\ Journal of Economic Development, Environment and People \\ Volume 7, Issue 4, 2018
}

URL: http://jedep.spiruharet.ro

e-mail: office jedep@spiruharet.ro

independent variables in this research affect the dependant variable. In other words, variations in the personal consumption are likely to be explained by variations in the four types of income.

Table no.3 Growth rates of incomes and consumption on a yearly basis

\begin{tabular}{|c|c|c|c|c|c|}
\hline Year & Income from property & Income from insurance & Wages and salaries & Income from small business & Consumption \\
\hline & \multicolumn{5}{|c|}{ Growth rate (\%) } \\
\hline 2015 & 234.95 & 16.34 & -3.45 & 15.41 & -1.19 \\
\hline 2014 & -23.54 & 0.05 & -4.91 & 347.34 & 19.46 \\
\hline 2013 & -51.47 & 26.82 & 16.49 & -72.45 & -0.13 \\
\hline 2012 & -67.15 & -21.57 & 4.91 & 146.06 & 13.75 \\
\hline 2011 & 243.64 & 25.16 & -0.047 & -12.35 & -3.21 \\
\hline 2010 & -49.09 & 2.41 & -6.33 & -14.8 & -7.83 \\
\hline 2009 & -16.03 & -4.82 & 28.73 & 1057.81 & 2.15 \\
\hline 2008 & - & - & - & - & - \\
\hline
\end{tabular}

All of the data on which these cross tabulations are based will be used in the next parts of this research, while conducting the regression analysis. While first table showed only results in a form of trends, such as increases and decreases, this table shows the actual change of the values during the period use for this research. Changes are presented as growth rates, shown in percents and they are based on the calculating the variations in every variable independently. The growth rates are comparisons of the values between the certain year and its last year. For example, growth rate of income from pension insurance on the level of $25.16 \%$ show the increase compared to the value of that variable in the year of 2010 . As the first year on which comparisons are made is the year 2008 , there is no growth rates created for this year.

Table no. 3 can clearly show the mentioned changes in the income from small business. The first growth rate is enormous and it probably had positive impact on the variations in consumption. But, it looks like growth rate of consumption for the year 2009 does not accompany the huge variation as in the income from small business. It is possible that new big earnings are often saved for the later usage. Maybe that money crossed the national border and maybe it was used for investments, so that small business can become a big financial organization.

The positive impact of big changes in the income from small business can be also seen through growth rate for the year 2012. The independent variable again had dynamic variations, so it is very possible that the growth rate of $146.06 \%$ for the value of income from business made effect to the variations in the consumption, whose value also shows big increase on the level of $13.75 \%$. Therefore, this table fulfills the relations shown in previous cross tabulations. 


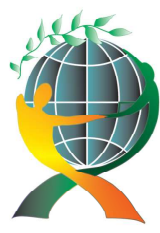

\author{
(online) $=$ ISSN $2285-3642$ \\ ISSN-L = $2285-3642$ \\ Journal of Economic Development, Environment and People \\ Volume 7, Issue 1, 2018 \\ URL: http://jedep.spiruharet.ro \\ e-mail: office jedep@spiruharet.ro
}

\title{
2.4. Data collection
}

While conducting this research, several methods of data collection were applied. In general, most of the information is gather online, by visiting web sites of famous economic institutions, national and international. The reason for this situation is that they are specialized in the field of economic research and offer free usage of data, which they have in possession. Those institutions follow international standards of data collection and they are obligated by law to perform such activities or they perform those activities as non-obligatory, but under the framework of legislative.

In the first part of the research, it was important to define what the subject is and which factor could be relevant for the usage in this research. Before using any public information offered by various organizations, observation and logic were used to evaluate the potential relations between numerous variables. Before entering the fieldwork and appliance of the techniques, understanding the theory is the most important factor for every research. For example, if you think about money supply many factors can be related to its values. However, not just that trying the analysis with many different factors can take too much time and money, but can also be irrelevant at the end. If we think that production in some industry can be crucial for determination of the value of money supply we can easily be wrong. Their correlation would probably exist, but more indirectly than directly and with the limited variations of money supply explained. If you are doing this kind of research, then it is important to understand the logic behind it, based on the economic theory. So, in this case it would seem more likely that active interest rates would have direct impact on the money supply. Why? Because, depending on the level of interest rates people will take certain quantity of money from the bank. Depending on interest rates, people will also give certain quantity of money to the bank. Therefore, the money will be created on that way and more money will circulate in the economy.

Following that logic based on observation of economic processes, variables have been chosen for this research. While thinking what would have a great impact on the consumption, it was significant to understand the theory behind it. What makes all of the consumptions possible? If "there is no free lunch", we can imagine that there is a source for every consumption. Money is needed for buying products and services, which we consume during our entire lives. In addition, we are the civilization based on consumption. While industrial revolution created society based on production, we now live in the time where people are consumers before anything else. Post effects of industrial revolution created economic and living conditions in which we have too many options for every need. If you want to buy soda, you will have to choose between twenty brands in a store, or between hundreds of brands in the world. Nevertheless, economic logic behind it tells us that everything has a price. So the other side of the consumption is the resource. In this research, resources are shown though economic indicators such as incomes. Moreover, there are many types of incomes. You can get through working for a private company or the government, in which case you will gain salary. As every service has its price, so does the service of 


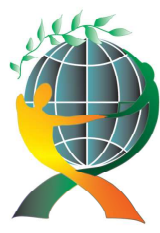

\author{
(online) $=$ ISSN $2285-3642$ \\ ISSN-L = $2285-3642$ \\ Journal of Economic Development, Environment and People \\ Volume 7, Issue 4, 2018 \\ URL: http://jedep.spiruharet.ro \\ e-mail: office jedep@spiruharet.ro
}

your work. In that sense, salary is nothing else but the price of work. On other hand, if you own a company you can earn profit, which is in the economic terms referred as income from business. Other types of income include dividends, gained from companies in which you are a partly owner. Also, there are ways to earn money from your property, receive pension if you are retired or receive money from various types of insurance.

So which incomes are best in defining the level of consumption? Leading the theory that a majority of the people in Montenegro is working population and people who are in retirement, incomes from pension insurance, wages and salaries are the main source, which covers the consumption. Since this research analyses the total personal consumption, it is wise to use more types of incomes. So the next types have been chosen by realizing through observation and through statistical results used from national and international organizations that big impact on consumption are created by incomes from business and property. Statistical reports of the National statistical office of Montenegro were the first science based evidence that property is a popular way of gaining money in Montenegro. Except for that, it is understandable and easily proved by many big economic organizations, national and international economies are based on the activities of small and medium sized businesses. Since there are much more small businesses in Montenegro, especially if we count domestic entrepreneurs, it was recognized by the National statistical office that income from small business specially creates an impact on the consumption.

All of the data that is used in this research is collected through reports of the statistical organizations. So it is important to realize which techniques lie behind those data collections. Methods used for collection are based on the usage of questionnaires conducted through interviews. There are many reasons why this was appropriate method and therefore, the data for this research. First, interviews for these data were done in person and by specially trained people to do that. Most of the data, especially for the regression analysis, are collected under the constitution of law, which guarantees a higher quality of the data collected. In comparison to the social networking where there is no verification of the information provided by the respondents.

Usage of questionnaires also has advantages for this research, because responses can be analyzed with quantitative methods by assigning numerical values. Having in mind that this research is based on statistics, numerical values are preferable. Also, data collection conducted by institutions which are tied to these activities by law, do the pretests which can be compared and analyzed. So that is one more evidence that attention to the quality of data has been paid.

Not only reports from statistical institutions have been used. For this research, another method of data collection was relevant. It refers to documents and records, also gained from government institutions. They consist of examining data in the form of databases, registers and financial records. They were important for identifying statistical units used for this research. Most of all, they were a good starting point for creating a new base of carefully chosen data. That database is a resource of statistical information, on 


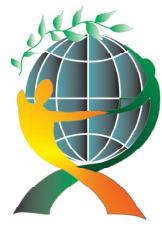

\author{
(online) $=$ ISSN $2285-3642$ \\ ISSN-L = $2285-3642$ \\ Journal of Economic Development, Environment and People \\ Volume 7, Issue 1, 2018 \\ URL: http://jedep.spiruharet.ro \\ e-mail: office jedep@spiruharet.ro
}

which the regression analysis is conducted. In this research, the main method of examination and analysis is not based on questionnaires. Thou questionnaires have been used by other institutions and their results were the secondary data used for this research, direct collection for regression analysis is based on creating the new database. The created database is based on reducing the statistical material on the level that is only important for the subject. For example, there were not used data for all types of incomes, but only for four types. Also, there were not used data about specific types of consumptions such as food, clothes etc. But, it is created on the selection of data which are in consensus to the objectives of this research and the hypothesis which have to been tested in order to get the expected results.

Documents and records are a good way for collection of data for this research, because first of all, it is a student project. So, the budget is very limited and this way of data collection is inexpensive, provides a good background information and may provide knowledge gained through times which are not noted by other means. Also, all other methods used for this research are based on secondary data. All the information has already been collected, processed and reported by other institution and this is the reason for those sources to be very advantageous. That not only can give an opportunity to review the data available for this project before potential collection of primary data, but also tells us which questions need to be addressed. Secondary data used for this research are appropriate for another reason, because their collection is based on fieldwork. On that way, the data need to be sufficiently descriptive. They must be factual, accurate and cleared from irrelevant information that can be gained through the process. So it is important for creating the database used for regression analysis. In addition, regression analysis has been a carefully chosen method for the research. Because, the essential results of this research will show what the relationship between the incomes and consumption is. In which extent their correlation is relevant, are the chosen incomes sufficient to explain the variations in the level of consumption during the years. By using these data and analysis, we will find what lies behind consumption and understand the households as main consumption units on the market.

\title{
2.5. Research and analysis evaluation
}

After starting the regression analysis in the SPSS program for four independent variables and one dependent variable it is required to explain obtained tables and graphs so we can understand the statistical analysis, regression model and the essence of this project. 


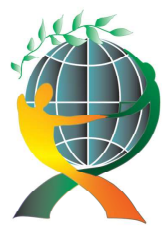

\author{
(online) $=$ ISSN $2285-3642$ \\ ISSN-L = $2285-3642$ \\ Journal of Economic Development, Environment and People \\ Volume 7, Issue 4, 2018
}

URL: http://jedep.spiruharet.ro

e-mail: office jedep@spiruharet.ro

Tables number 4 and 5:

Variables in the model and the model of summarized statistics

\begin{tabular}{|c|c|c|c|}
\hline \multicolumn{4}{|c|}{ Variables Entered/Removed ${ }^{a}$} \\
\hline Model & $\begin{array}{l}\text { Variables } \\
\text { Entered }\end{array}$ & $\begin{array}{l}\text { Variables } \\
\text { Removed }\end{array}$ & Method \\
\hline 1 & $\begin{array}{l}\text { Income from } \\
\text { small } \\
\text { business, } \\
\text { Income from } \\
\text { property, } \\
\text { Wages and } \\
\text { salaries, } \\
\text { Income from } \\
\text { pension } \\
\text { insurance b }\end{array}$ & . & Enter \\
\hline \multicolumn{4}{|c|}{$\begin{array}{l}\text { a. Dependent Variable: Personal consumption } \\
\text { b. All requested variables entered. }\end{array}$} \\
\hline
\end{tabular}

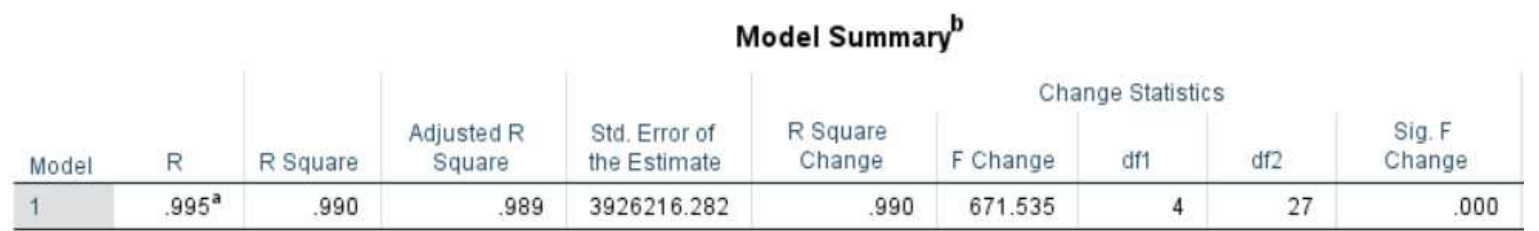

a. Predictors: (Constant), Income from small business, Income from property, Wages and salaries, Income from pension insurance

b. Dependent Variable: Personal consumption

Variables are entered by "Enter" method, which means that all entered variables remained in the regression model, which is based on a multiple regression equation, in which the independent variables are "Income from pension insurance", "Income from property", "Income from small business" and "Wages and salaries", while the dependent variable is "Personal consumption".

Table 2 shows main information about the validation of regression mode, and those are: Determination coefficient R Square, which is shown in the second column, amounts 0.995 which actually tells that $99.5 \%$ of variability in dependant variable "Personal consumption" is explained by variations in four independent variables entered in model. More precisely, these four independent variables explain 99.5\% of "Personal consumption".

Sig. F Change amounts 0 which is lower than 0.05 and actually means that we should reject the null hypothesis Ho, which presents the assertion of value of population and in this case represents assertion that adding new variables in the model cannot significantly affect the regression model, therefore cannot affect the R Square. Regarding that $\mathrm{Ho}$ is rejected, conclusion is made that entering the new variables in the model can significantly affect an increase of determination coefficient. 


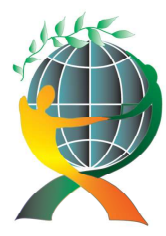

\author{
(online) $=$ ISSN $2285-3642$ \\ ISSN-L = 2285 - 3642 \\ Journal of Economic Development, Environment and People \\ Volume 7, Issue 1, 2018
}

URL: http://jedep.spiruharet.ro

e-mail: office jedep@spiruharet.ro

Tables no. 6 and no.7

ANOVA table and Table of coefficients

\begin{tabular}{|c|c|c|c|c|c|c|}
\hline \multicolumn{7}{|c|}{ ANOVA $^{a}$} \\
\hline \multicolumn{2}{|c|}{ Model } & $\begin{array}{l}\text { Sum of } \\
\text { Squares }\end{array}$ & df & Mean Square & $\mathrm{F}$ & Sig. \\
\hline \multirow[t]{3}{*}{1} & Regression & $4.141 \mathrm{E}+16$ & 4 & $1.035 E+16$ & 671.535 & $.000^{\mathrm{b}}$ \\
\hline & Residual & $4.162 \mathrm{E}+14$ & 27 & $1.542 E+13$ & & \\
\hline & Total & $4.182 \mathrm{E}+16$ & 31 & & & \\
\hline \multicolumn{7}{|c|}{ a. Dependent Variable: Personal consumption } \\
\hline \multicolumn{7}{|c|}{$\begin{array}{l}\text { b. Predictors: (Constant), Income from small business, Income from property, Wages } \\
\text { and salaries, Income from pension insurance }\end{array}$} \\
\hline
\end{tabular}

\begin{tabular}{|c|c|c|c|c|c|c|c|c|c|c|c|}
\hline \multicolumn{12}{|c|}{ Coefficients $^{a}$} \\
\hline \multirow{2}{*}{\multicolumn{2}{|c|}{ Model }} & \multicolumn{2}{|c|}{ Unstandardized Coefficients } & \multirow{2}{*}{$\begin{array}{c}\text { Standardized } \\
\text { Coefficients } \\
\text { Beta }\end{array}$} & \multirow[b]{2}{*}{$t$} & \multirow[b]{2}{*}{ Sig. } & \multicolumn{3}{|c|}{ Correlations } & \multicolumn{2}{|c|}{ Collinearity Statistics } \\
\hline & & $\mathrm{B}$ & Std. Error & & & & Zero-order & Partial & Part & Tolerance & VIF \\
\hline \multirow[t]{5}{*}{1} & (Constant) & -1683403.715 & 3825208.207 & & -.440 & .663 & & & & & \\
\hline & Wages and salaries & .023 & .137 & .008 & .169 & .867 & .871 & .033 & .003 & .158 & 6.310 \\
\hline & $\begin{array}{l}\text { Income from pension } \\
\text { insurance }\end{array}$ & 3.843 & .226 & .899 & 17.019 & .000 & .990 & .956 & .327 & .132 & 7.565 \\
\hline & Income from property & 12.285 & 3.916 & .079 & 3.137 & .004 & .483 & .517 & .060 & .583 & 1.715 \\
\hline & $\begin{array}{l}\text { Income from small } \\
\text { business }\end{array}$ & 4.042 & 1.613 & .075 & 2.506 & .019 & .735 & .434 & .048 & .416 & 2.402 \\
\hline
\end{tabular}

By table 6 is tried to determine does at least one of the independent variables explain properly the dependent variable in the model. ANOVA table shows shares of explained and unexplained variations. The value of significance is Sig.= .000 which tells us that at least one independent variable in the model explains properly the dependent variable. Comparing the evaluated values of $F$ test with the table value is also stepped up in the zone of rejecting the null hypothesis which states that neither one of the independent variables does not explain the dependant variable. So the conclusion through ANOVA table is that at least one independent variable explains properly the dependent variable.

Table of coefficients shows how much which independent variable in the model contributed to prediction of the value of dependent variable. Based on not standardized $B$ coefficients in the table "Coefficients" is created a regression equation $Y^{\wedge}=.023^{*} X 1+3.843^{*} X 2+12.285^{*} X 3+4.042^{*} X 4$, where the independent variables are:

$\mathrm{X} 1$ - Wages and salaries

$\mathrm{X} 2$ - Income from pension insurance

X3 - Income from property

$\mathrm{X} 4$ - Income from small business 


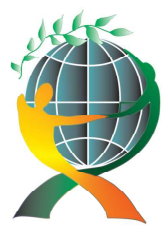

\author{
(online) $=$ ISSN $2285-3642$ \\ ISSN-L = 2285 - 3642 \\ Journal of Economic Development, Environment and People \\ Volume 7, Issue 4, 2018 \\ URL: http://jedep.spiruharet.ro \\ e-mail: office jedep@spiruharet.ro
}

While the dependant variable $Y^{\wedge}$ is Personal consumption. Coefficient a amounts .023 and presents the value of dependant variable when the independent variables are equaled to zero. Coefficient $b$ presents for how much will the dependant variable change if the independent variable $X 2$ is increased by 1 unit, while other independent variables stay unchanged. From the equation is clear that Income from property has the biggest influence on the Personal consumption and that if the Income from property is increased by 1 unit, there will be an increase of Personal consumption by 12.285 Euros. In addition, coefficient $d$ amounts 4.042 and creates a positive effect on the personal consumption, meaning that the increase of profit will increase the personal consumption.

These results show that assumptions regarding the relations between the independent and dependent variables came true, meaning that there is a positive correlation among them. To create a proper image of the effects on personal consumption, these results are not obligatory and certainly not enough.

Before every explanation of results, we should do the logic tests first. For example, the equation shows that wages and salaries do not create a significant effect on the personal consumption. That is strange, because wages and salaries are the main type of income for majority of households. Not every household owns a business or property, so it is strange that the biggest effect on the consumption will have income from property. These variations can be explained by understanding the economic conditions, which could not have been included in this research. For example, real estate market had big changes during the last decade, which can result with the dynamic effects of incomes from property on the personal consumption. Also, every country is based on small and medium sized companies and it is logical that the increase of profits will be a step which leads to the increase of property purchases. Table of correlations will make it clearer whether these relations among variables are exactly as in the equation. With this more sophisticated instrument, can be shown more precise results of the statistical analysis.

Column Sig. for almost every independent variable is lower than 0.05 that shows that independent variable explains the dependant variable. That can be checked by individual $t$ tests for every independent variable, where the $t$ value of variables are in the zone of rejecting the null hypothesis, having in mind that Ho states that coefficient $B$ is equal to zero and that the independent variable does not explains the dependent variable. These results are in the same table as with the values of the coefficients of variables, so they should also be compared with the rest of the statistical results in the regression analysis.

Based on standardized coefficient Beta, the conclusion is made that the biggest effect on the Personal consumption is created by Income from pension insurance; regarding that absolute value of that coefficient is the highest (.899). This is a first sign that the impacts of independent variables on the dependent variable shown through equation are not the final results on which we can create the image of correlations among the variables. These results show that the biggest effect is not created by income from property, which can be more logical because the majority of population in Montenegro represents the people in retirement, so the variations in this value can create a significant effect on the total personal consumption of households. 

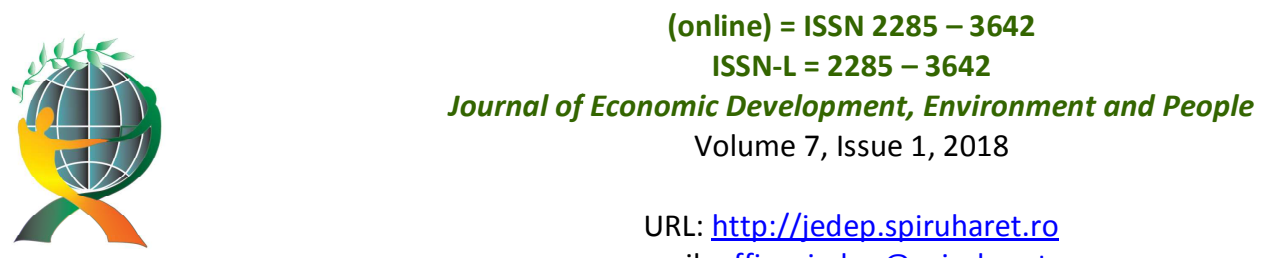

URL: http://jedep.spiruharet.ro

e-mail: office jedep@spiruharet.ro

Still, as for the previous results obtained through equation, we should take in consideration the rest of the results before making a definitive conclusion. Table of correlations and graphs will complete the analysis.

Table of Coefficients shows some more results. Level of tolerance (Tolerance) shows if there is a multicollinearity and because in this case it is not lower than 0.1 , coefficient shows that there is no problem of multicollinearity. In other words, there is no connection between the independent variables. That also shows VIF, which is obtained as a reciprocal value of level of tolerance. If the average VIF is not higher than 10 it proves the absence of problem of multicollinearity. So this is another assumption of the regression analysis which is satisfied.

Table no.8 Collinearity diagnostics

\begin{tabular}{|c|c|c|c|c|c|c|c|c|}
\hline \multirow[b]{3}{*}{ Model } & \multicolumn{8}{|c|}{ Collinearity Diagnostics $^{a}$} \\
\hline & \multirow[b]{2}{*}{ Dimension } & \multirow[b]{2}{*}{ Eigenvalue } & \multirow[b]{2}{*}{$\begin{array}{l}\text { Condition } \\
\text { Index }\end{array}$} & \multirow[b]{2}{*}{ (Constant) } & \multicolumn{3}{|c|}{ Variance Proportions } & \multirow[b]{2}{*}{$\begin{array}{c}\text { Income from } \\
\text { small } \\
\text { business }\end{array}$} \\
\hline & & & & & $\begin{array}{c}\text { Wages and } \\
\text { salaries }\end{array}$ & $\begin{array}{c}\text { Income from } \\
\text { pension } \\
\text { insurance }\end{array}$ & $\begin{array}{c}\text { Income from } \\
\text { property }\end{array}$ & \\
\hline \multirow[t]{5}{*}{1} & 1 & 4.787 & 1.000 & .00 & .00 & .00 & .00 & .00 \\
\hline & 2 & .136 & 5.936 & .04 & .01 & .00 & .02 & .33 \\
\hline & 3 & .039 & 11.033 & .01 & .04 & .13 & .48 & .05 \\
\hline & 4 & .031 & 12.372 & .90 & .03 & .02 & .23 & .04 \\
\hline & 5 & .007 & 26.238 & .06 & .92 & .84 & .27 & .58 \\
\hline
\end{tabular}

a. Dependent Variable: Personal consumption

In the table, Collinearity Diagnostics through column Condition Index is possible to additionally test if there is a problem of multicollinearity. If the value of this index is higher than 30 , there is a multicollinearity. In this research, value of Condition Index for every variable is lower than 30 and according to these results, there is no problem of multicollinearity.

From the table 9 of residual statistics can be seen that the average value of residuals is equaled to zero, which represents another completed assumption of regression. Values of standardized residuals are in the interval from -1.535 to 1.288 , which actually means that there is no extreme value bigger than 3 standard deviations which can significantly affect the regression. That also proves Cook's Distance, which if it is higher than 1 means that there is a individual value which affects the result of analysis, but in this case the maximum value of Cook's Distance is .102 which means that there is no such extreme value. 


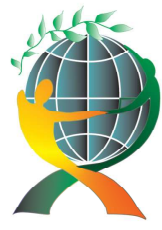

\author{
(online) $=$ ISSN $2285-3642$ \\ ISSN-L = 2285 - 3642 \\ Journal of Economic Development, Environment and People \\ Volume 7, Issue 4, 2018
}

URL: http://jedep.spiruharet.ro

e-mail: office jedep@spiruharet.ro

Table no 9. Residual Statistics

\begin{tabular}{|c|c|c|c|c|c|}
\hline & Minimum & Maximum & Mean & Std. Deviation & N \\
\hline Predicted Value & 88893584.00 & 176469328.0 & 126453167.2 & 36591578.96 & 32 \\
\hline Std. Predicted Value & -1.026 & 1.367 & .000 & 1.000 & 32 \\
\hline $\begin{array}{l}\text { Standard Error of } \\
\text { Predicted Value }\end{array}$ & 985084.813 & 1697023.625 & 1337959.138 & 203535.980 & 32 \\
\hline Adjusted Predicted Value & 90096592.00 & 175672112.0 & 126405109.1 & 36499411.72 & 32 \\
\hline Residual & -5253224.000 & 4409625.000 & .000 & 3194098.038 & 32 \\
\hline Std. Residual & -1.535 & 1.288 & .000 & 933 & 32 \\
\hline Stud. Residual & -1.669 & 1.410 & .006 & 1.020 & 32 \\
\hline Deleted Residual & -6212043.500 & 5395597.000 & 48058.086 & 3822630.713 & 32 \\
\hline Stud. Deleted Residual & -1.730 & 1.438 & .007 & 1.030 & 32 \\
\hline Mahal. Distance & 1.599 & 6.653 & 3.875 & 1.442 & 32 \\
\hline Cook's Distance & .000 & .102 & .040 & .031 & 32 \\
\hline Centered Leverage Value & .052 & .215 & .125 & .047 & 32 \\
\hline
\end{tabular}

a. Dependent Variable: Personal consumption

Table no. 10 Correlations

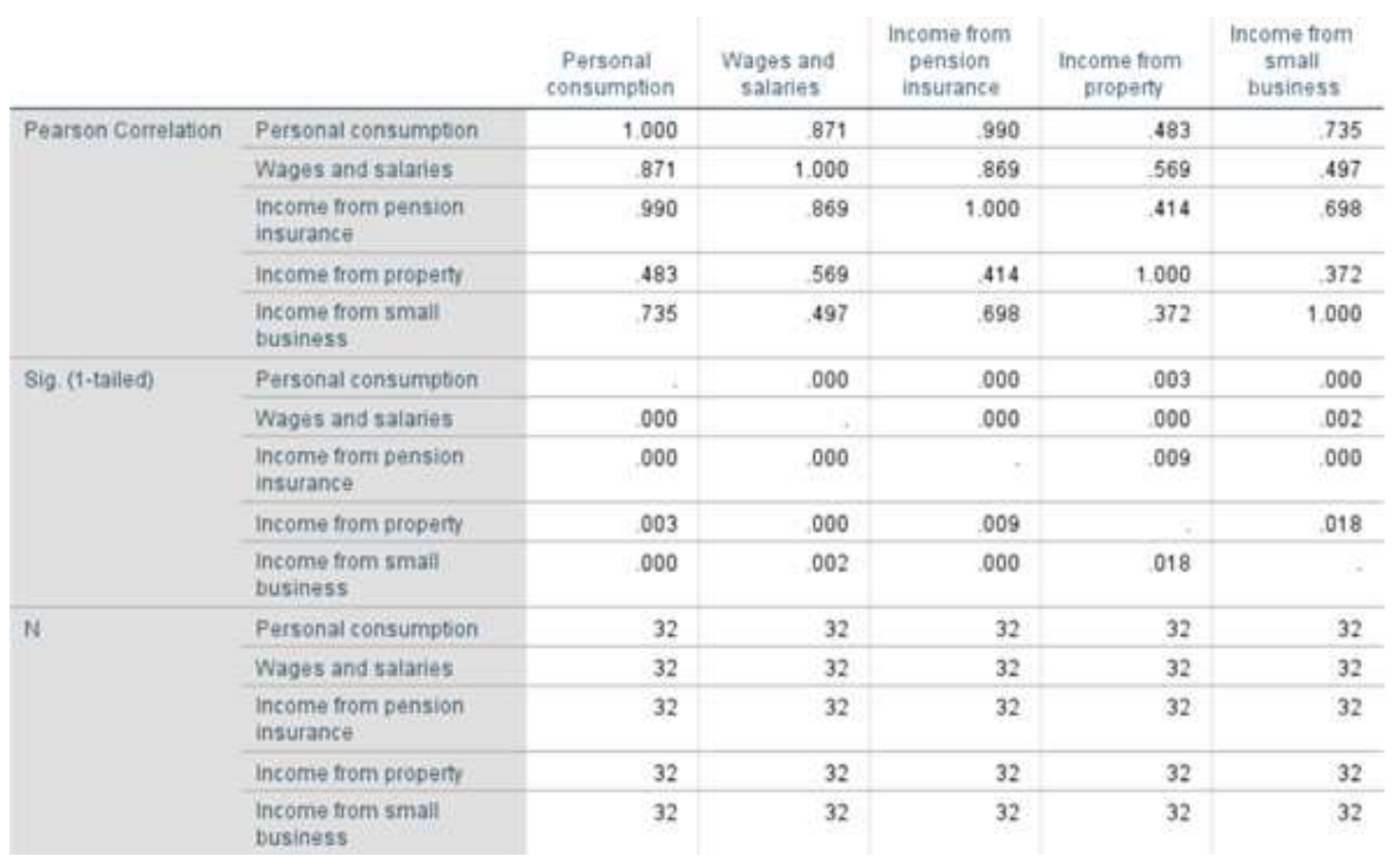




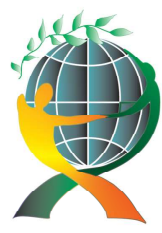

\author{
(online) $=$ ISSN $2285-3642$ \\ ISSN-L = $2285-3642$ \\ Journal of Economic Development, Environment and People \\ Volume 7, Issue 1, 2018 \\ URL: http://jedep.spiruharet.ro \\ e-mail: office jedep@spiruharet.ro
}

Table of correlations shows more precisely how do the independent variables affect the dependent variable. Some of the results are significantly different compared to the results obtained through regression equation. For example, wages and salaries have clearly bigger impact. Actually, $87.1 \%$ of variations in the dependent variable are explained by variations in Wages and salaries. In other terms, Wages and salaries explain almost $90 \%$ of the value of Personal consumption, thus is clear that this independent variable should stay in the model. As it was assumed above, it is not logical that income from property should have that big impact on personal consumption.

Table of correlations shows that around half of the variations in the Personal consumption are explained by variations in the Income from property. Although, these results do not mean that we should only take them in consideration. While making a conclusion, we should consider the results of the equation, correlations and other tables, along with the graphs results, which will be represented in this research. According to the results, the income from pension insurance has actually a big impact on the Personal consumption. Due to the assumed impact regarding the majority of people in Montenegro, which are retired people, table of correlations shows that exactly $99 \%$ of variations in the Personal consumption can be explained by variations in the Income from pension insurance.

As predicted profits create big impact on consumption, due to the evaluation that the economy of countries like Montenegro are based on small businesses, table of correlations shows that $73.5 \%$ of variations in dependent variable can be explained by variations in independent variable. In other words, 73.5\% of the value of Personal consumption can be explained by the value of Income from small business.

In combination with the results from rest of the tests conducted in this analysis, every independent variable is good in explaining the value of the dependent variable "Personal consumption", thus it is wise to keep these independent variables in the model. They have not only passed the correlations test, but also the various multicollinearity tests, as well as the ANOVA test and summarized statistics model, which shows that this model is valid for estimation of the dependent variable.

One more assumption that should be completed is existence of normal distribution of standardized residuals. That assumption can be tested by Histogram and P-P diagram of standardized residuals (Graph 1).

According to Histogram, normal distribution of standardized residuals is questionable, because there are clear deviations from expected value, so additional testing of normality is required. 

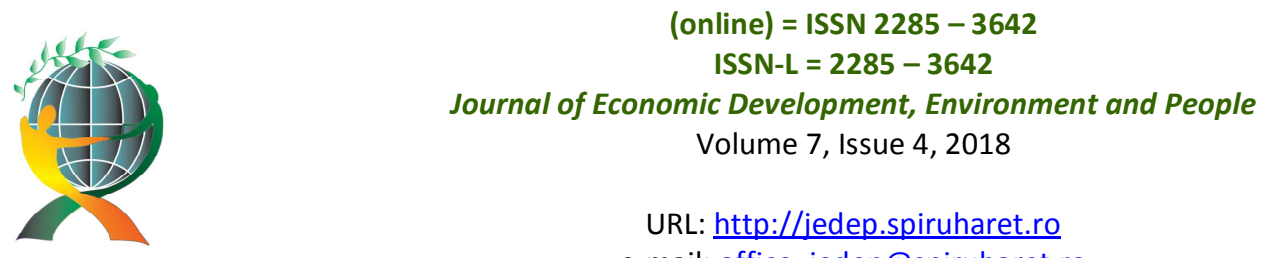

URL: http://jedep.spiruharet.ro

e-mail: office jedep@spiruharet.ro

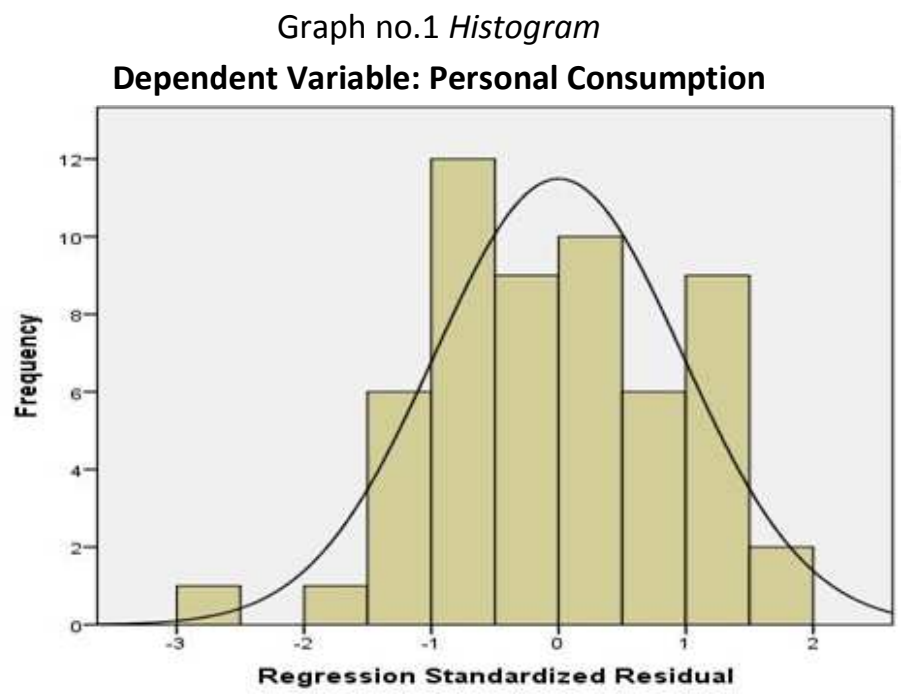

Graph no.2

Normal P-P plot of regression standardized residual

Dependent Variable: Personal Consumption

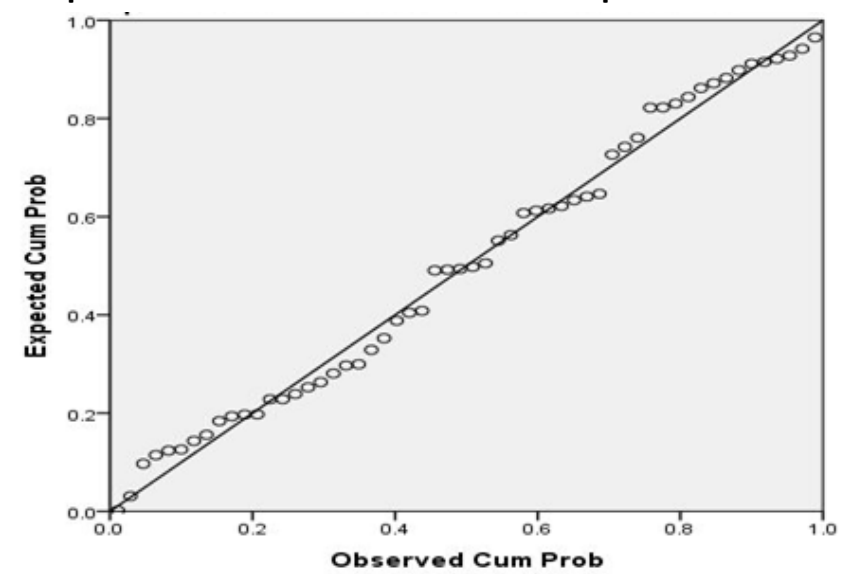

P-P diagram gives a clearer image of normality of standardized residuals. If the individual values are distributed on the line of regression, or in the mild cases very close to the line of regression, it can be claimed that there is a normality of standardized residuals. In this case, individual values are very close to the line of regression and it can be assumed that the normality exists. But, the best solution is to start the test of normality which gives the concrete results about the given subject. 


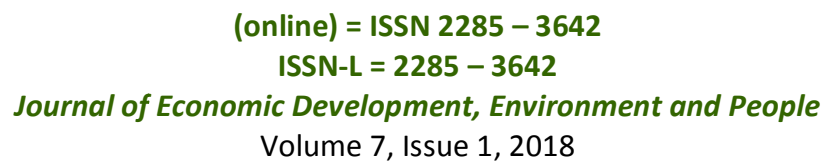

URL: http://jedep.spiruharet.ro

e-mail: office jedep@spiruharet.ro

Table no.11 Tests of normality

Tests of Normality

\begin{tabular}{|l|r|r|r|r|r|r|}
\hline & \multicolumn{3}{|c|}{ Kolmogorov-Smirnov $^{\text {a }}$} & \multicolumn{3}{c|}{ Shapiro-Wilk } \\
\cline { 2 - 7 } & Statistic & \multicolumn{1}{c|}{ df } & \multicolumn{1}{c|}{ Sig. } & Statistic & \multicolumn{1}{c|}{ df } & Sig. \\
\hline Standardized Residual & .079 & 56 & $.200^{*}$ & .972 & 56 & .224 \\
\hline
\end{tabular}

*. This is a lower bound of the true significance.

a. Lilliefors Significance Correction

Through conduction of Kolmogorov-Smirnov and Shapiro-Wilk tests of normality, can be correctly determine if certain variable is normally distributed. The null hypothesis Ho of this test defines that there is a normal distribution of certain variable and if the column Sig. is lower than 0.05 , the null hypothesis is rejected, so it states that normal distribution of variable does not exists. In this test, value of coefficient Sig. is in both cases higher than the critical value, which actually proves the theory that the normal distribution of the examined variable exists. In other words, the assumption of the normality of standardized residuals is proved and completed.

Graph no.3 Scatterplot diagram

Dependent Variable: Personal Consumption

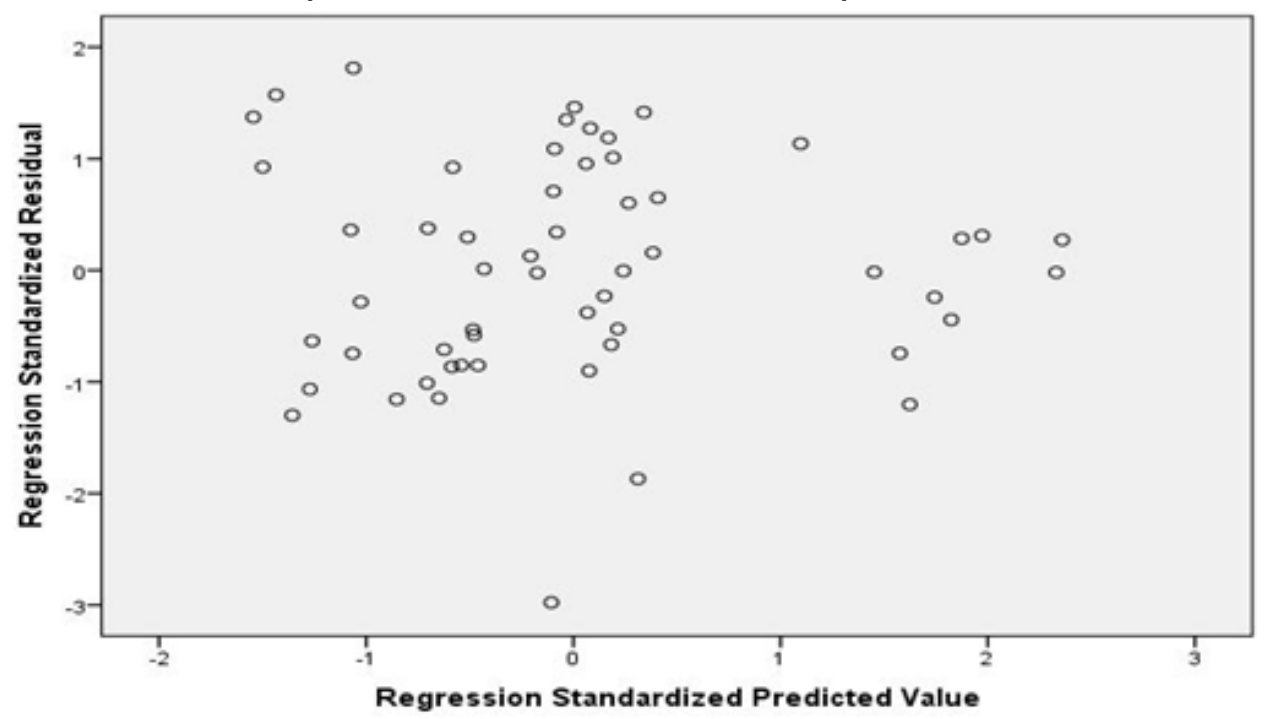




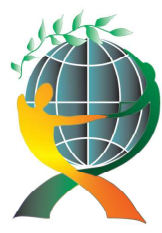

\author{
(online) $=$ ISSN $2285-3642$ \\ ISSN-L = $2285-3642$ \\ Journal of Economic Development, Environment and People \\ Volume 7, Issue 4, 2018 \\ URL: http://jedep.spiruharet.ro \\ e-mail: office jedep@spiruharet.ro
}

The last assumption that is left to test is the equality of the variances of residuals, in other terms the existence of homoscedasticity. Homoscedasticity is tested by Scatterplot diagram where if there is a dispersion of data in the diagram, in other words if there cannot be noticed any correctness (order, scheduled data) that means that the homoscedasticity exists. In this case, it could not be determined any order of the data, so the homoscedasticity do exists and variances of residuals are the same for all values of the dependent variable.

After testing all assumptions of linear regression and conducting the entire analysis, it can be concluded that the given regression is correct and the obtained results are valid. Logical expectations from the beginning of the research about the direction of movements of relations between the dependent and independent variables came true. In other words, all null hypotheses have been proved so the objectives are now achieved.

\title{
2.6. Ethics
}

Data used for this statistical research are gained through public access to information provided by the National statistical office of Montenegro. Since this research is based on households as statistical units, the primary data had been obtained through interviewing. These data are official secret and every participant in the survey must respect this. As a student/researcher, I do not have the possibility to access the filled questionnaires, neither any other person who was not officially included in conducting the survey. These data are hidden in safe places, so they cannot be seen in a public building or some form of transportation used for transfer of data between the institutions, which form the national statistical system. All data collected from the individual households and their members are confidential. While collecting the data, all respondents are informed that the confidentiality of these data is guaranteed. The data on an individual level cannot be accessed, because the results obtained through interviewing are published on the aggregated level. That is how the presentation of individual data is disabled.

The Law on Statistics and Statistical System of Montenegro regulates the standards regarding the confidentiality and protection of statistical data. There are several institutions responsible for production and publication of data and they are all obligated to respect the standards of confidentiality and protection of statistical data. The essence of this law is the principle on which is based on, that personal data must be used exclusively for statistical purposes. In the respect of this principle, statistical confidentiality represents the protection of data related to individual statistical unit. In addition, statistical units from which the primary data are collected have been chosen only for statistical purposes. For secondary data, if the data are obtained indirectly from administrative or other sources, the law still has to be respected. That means that the protection from using data in non-statistical purposes and unlawful publications is provided. Although, this principle of statistical confidentiality does not apply to the statistical data on public administration bodies. Since this is a student research, conducted through usage of public information, all 


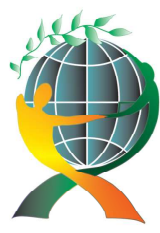

\author{
(online) $=$ ISSN $2285-3642$ \\ ISSN-L = $2285-3642$ \\ Journal of Economic Development, Environment and People \\ Volume 7, Issue 1, 2018 \\ URL: http://jedep.spiruharet.ro \\ e-mail: office jedep@spiruharet.ro
}

the activities have been completed with the respect of the Law on Statistics and Statistical System of Montenegro.

Based on this law regarding the confidentiality of individual data on the natural or legal persons are represented as an official secret. This means that direct or indirect identification of natural or legal persons is not allowed and possible. In the purpose of providing this service quality, all measures of administrative, technical or organizational nature are undertaken. These activities are needed for the protection from unlawful access, disclosure or use. These standards are guaranteed during the implementation of many big statistical actions, such as census of population, dwellings, agricultural census. Also, these standards are respected during the collection, classification, processing, analyses and publications of data for household budget and thus, for the household consumption survey. While conducting these activities enumerators, instructors, controllers and other persons involved in the statistical process keep confidential all information obtained through interviewing.

In the end, while processing data, interviewed persons' name and surname are not captured in. Until the processing is completed, the data are kept properly and stored safely. When the statistical project is finished, all the questionnaires and hard copy forms of data are destroyed, so there are only public information on aggregated level, provided through the national statistical system, from which the data for this research have been used.

\title{
3. Target audience
}

While constructing the research, first it was important to determine which part of the population is significant for examination. The basic statistical units used for this research are households. Data on which the analysis is based are collected from the National statistical office of Montenegro. The statistical office collected the data through survey method and their survey unit was any sampled household. That means that households constituted of one or more persons were valid for research. The term "household" is talking about a group of persons living together or a person who lives alone in a separate housing unit. What is important is the relationship inside the household. For example, a household consisted of several persons is valid for this research if the members are spending their income on food and other crucial products and services, necessary for living. These households are usually families. On the other hand, if a household consists in one person who lives in a separated housing unit, it is valid for research if the person is spending his/her income separately.

Household structure is flexible. Its members can be temporarily absent for many reasons. For example, if the member is serving the military or is in prison less than 12 months, it is covered by the survey. It is the same for students; they are counted in the household regardless of the period of absence during the studies. Also, if the member of household is absent due to work responsibilities, it won't exclude the member from survey if the member is not abroad for period longer than 12 months. The essential to this 


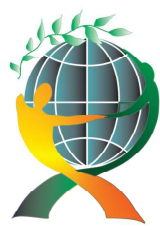

\author{
(online) $=$ ISSN $2285-3642$ \\ ISSN-L = $2285-3642$ \\ Journal of Economic Development, Environment and People \\ Volume 7, Issue 4, 2018 \\ URL: http://jedep.spiruharet.ro \\ e-mail: office jedep@spiruharet.ro
}

method is the finance that is bounded to the household. Therefore, the members must spend their incomes on food and other essentials together.

If some members do not participate in group expenditures, then they are analyzed as a separate household inside the housing unit. That means that all members share the housing unit, but have separate incomes and consumptions. For example, it is common that student roommates represent this type of statistical unit. There are more exclusions from the survey except from the time limitation of their absence. Members of so called collective households are not relevant for this research. Collective households mean it on hospitals, schools, prisons, private, government and religious institutions, etc. The main reason for them not being valid is that these persons have no fixed residence. Only in cases when person stays in the collective household less than six months and is financially linked to the household can be covered by the survey. Also, guests and similar persons who are only temporarily present are not relevant for this research and are not covered by the survey conducted by the National statistical office.

\title{
4. Conclusions
}

All statistical units important for this research are based on households on the territory of Montenegro. Data collected through survey is conducted for all parts of the country, rural and urban areas. This data collection is conducting during the entire observed year (from 1 January to 31 December). Relevant information for this research and the household budget survey are related to income and consumption. During this time any household is observed for a month. The analysis of the household includes behavior through calculating the expenses and incomes. Every year, around 192197 households are estimated. After the collection, the data are processed. In the end an average value of their incomes and consumptions is created.

All parts of the household budget survey are conducted with the appliance of the standards of EUROSTAT, statistical office of European Union, while also respecting the standards of International labor organization. The survey applies the method of keeping diary and interview method. Interviewing households is based on questionnaire. It is important to know that a household keeps the diary about their consumption for the period of one month. Specially trained interviewers do all of the parts of data collection based on the questionnaire. In order to provide assistance to data collection they are strongly advised to make at least three visits to a household.

While choosing the right target audience it was crucial to understand that research is based on all residents in Montenegro. The sampling was created with the consideration of number of people in Montenegro, as well as with their financial flows related to this territory and financial obligations inside the households as statistical units. 


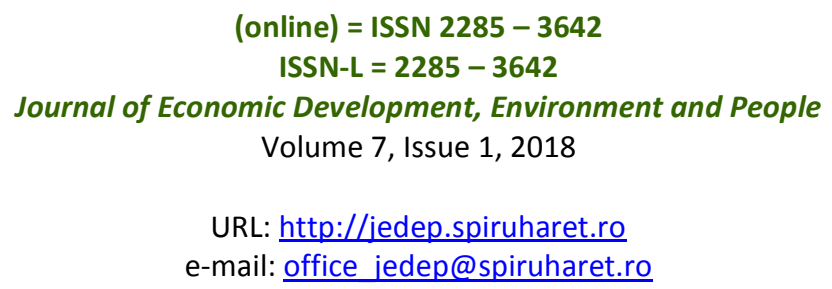

\section{References}

[1] F. Magrabi, S. Sohn Cha, Y. S. Chung. The Economics of Household Consumption. Greenwood Publishing Group, 1991.

[2] S. Pachauri. An Energy Analysis of Household Consumption: Changing Patterns of Direct and Indirect Use in India. Spinger, 2007.

[3] D. Dean, M. Overton. Production and Consumption in English Households 1600-1750. Routledge, 2005.

[4] P. Musgrove. U.S. Household Consumption, Income, and Demographic Changes: 1975-2025. Routledge, 1982.

[5] K. Wheeler, M. Glucksmann. Household Recycling and Consumption Work: Social and Moral Economies. Spinger, 2015.

[6] A. Deaton. The analysis of household surveys. The John Hopkins University Press, 1996.

[7] R. R. Dholakia. Technology and Consumption: Understanding Consumer Choices and Behaviors. Springer, 2012.

[8] J. Baudrillard. The Consumer Society. SAGE Publications, 1970.

[9] F. G. Cheo. The Effect of Monetary Policy on Household Consumption in Cameroon. GRIN Publishing, 2016.

[10] J. Davies. The European Consumer Citizen in Law and Policy. Palgrave Macmillan, 2011. 